\title{
BÁN Katalin \\ Médeia, a gyermekgyilkos az antik görög lélekfogalom tükrében
}

A tanulmányban Médeia, a gyermekgyilkos asszony antik mítoszának korabeli értelmezésére, lélekfilozófiai szempontból történő megközelítésére vállalkozom. Már az ókori görög világban több gondolkodó, író, költő értelmezte az asszony lelkében dúló destruktív érzelmi folyamatokat, s használta fel Médeia esetét legtöbbször exemplumszerüen saját nézetei alátámasztására.

A saját pszichéről való gondolkodás fontossága, elmélete és annak technikája Euripidés Médeiájában már megjelenik, s olyan neves filozófusok hangsúlyozzák jelentőségét, mint Sókratés, Platón vagy Aristotelés. Az antikvitásban több gondolkodó, filozófus idézte e mü kulcsfontosságú sorait (1078-1080) a lélek destruktív indulati folyamatainak példájaként vagy lélekfilozófiai téziseik igazolására: „Tudom, hogy szörnyü bün, amit merészelek, / de elmémnél hatalmasabb a szenvedély, / az emberek legtöbb bajának fö oka."1

Médeia az összes fennmaradt irodalmi szövegben önmagát elemezve áll előttünk. Beszédéből kitűnik, hogy valamilyen mértékben (szerzőtől függően) tudatában volt készülő tette kegyetlen, elítélendő mivoltának, hiszen értelmezte a magában dúló destruktív indulatokat. Módosult tudatállapotában azonban felerősödtek személyiségének romboló árnyékvonásai, $\mathrm{s}$ a pusztítást választotta. Médeia nem képes erényes emberként megoldani életének nagy krízishelyzetét, indulatai örvényként sodorják a gonosz tett felé. Az asszony története a női lét legnagyobb kihívásait, legmélyebb konfliktusait, az élet határhelyzeteinek kríziseit mutatja be, ami - a többi mítoszhoz hasonlóan - bizonyítja az ókori görög-római kultúra emberének intuitív gondolkodását, szimbólumok iránti fogékonyságát.

Az archaikus írók, költők tisztában voltak a szerelem, a szerelmi vágy igen erős, de szélsőséges emocionális és lélektani aspektusaival. A tragédiákról általánosságban

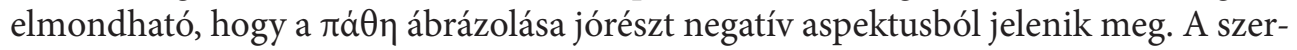
zők az emberi személyiség „árnyékának” veszélyeire hívják fel a figyelmet, felhasználva a mitológiai történetek hőseinek negatív, érzelmektől vezérelt tetteit. Filozófiai

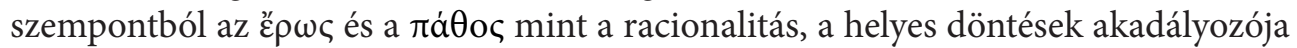
jelenik meg.

Az Állam című művében Platón az emberi lelken belül három különálló lélekrészt különböztet meg: a gondolkodó lélekrészt, amelynek feladata a lélek egészének ésszel

${ }^{1}$ Eur. Méd. 1078-1080. A dráma magyar szövegére Kerényi Grácia fordításában hivatkozom, az alábbi kiadás alapján: EuRIPIDÉsz Összes drámái, Bp., Európa, 1984, 115-163. 
történő, racionális irányítása; az indulatos lélekrészt, amelynek elemi működése a harag, de a győzelem és a megbecsülés motivációja is innen eredeztethető; illetve a vágyakozó lélekrészt, amely elsősorban a fizikai szükségletek vágyaiért felelös. Platón szerint a helyes életvezetés elérése érdekében az értelmes, az ész által vezérelt lélekrészre kell hallgatnunk, s nem szabad hagynunk, hogy vágyaink, indulataink felülírják ennek parancsait. ${ }^{2}$ Ily módon az érzelmek és a racionalitás folytonos versengése figyelhető meg: bár az emóciók szükséges velejárói az emberi létezésnek, az észnek mindig ellenőrzése alatt kell tartania azokat. Elméletének kiváló illusztrációja Törvények címü műve egyik hasonlata (644d-645a), amelyben az egyik beszélő arról értekezik, hogy az ember egyfajta báb, amelyet az érzelmek és a vágyak „zsinórjai” rángatnak, s csak az egyetlen aranyszál, az értelem vezetheti a helyes irányba. A platonikus filozófiát vallók Médeia esetét e lélekrészek konfliktusaként értelmezik.

Aristotelés lélekfilozófiai gondolkodásában az emóciók nem szükséges „rosszak”, hanem természetes velejárói az emberi életnek. Aristotelés szerint az erény éppúgy, mint a „lelki rosszaság”, tőlünk függ, azaz tetteink célját, eljárását és eszközeit szabad akaratunkból választhatjuk meg, s ezáltal a cselekvés személyes felelőssége válik hangsúlyossá: „a mondás, hogy »senki sem készakarva lesz gonosszá, sem pedig akarata ellenére boldoggá «, szerintünk felerészben hamis, s csak felerészben igaz. Mert boldoggá valóban senki sem akarata ellenére lesz; de már a gonoszság saját akaratunkból folyik."

Aristotelés megkülönbözteti a tudatlanságból és tudatosságból elkövetett cselekvést, gonoszságot. Szerinte csak úgy mondható el valakiről, hogy akarata ellenére cselekedett, ha nincs tudatában a cselekvés körülményeinek, és később felismeri és megbánja tettét. Saját akaratból történő cselekedetnek Aristotelés szerint azt kell tartanunk, „aminek mozgató elve magában a cselekvő személyben van; s aminek egyedi körülményeit, melyek közt a cselekvés végbemegy, a cselekvő személy ismeri”. Aristotelés filozófiája alapján tehát saját akaratból történő cselekedetnek nevezhetjük Médeia gyilkosságát, hiszen tudatában volt tette céljának, módjának és eszközének, emberi gonoszságát szabadjára engedve kielégítette bosszúvágyát gyermekeinek meggyilkolásával, ily módon súlyos felelősség terheli.

Aristotelés igen éleslátóan fogalmaz a haragról, annak helyes és helytelen kezeléséről, a harag helytelen kezelésével összefüggésben jelentkező indulati cselekvésről, a bosszúról, s az azzal járó örömről. Médeia haragjának intenzitását meghatározta, hogy férje, gyermekei apja iránt érzett haragot, s ezt csalódásának fájdalma, nőiségének megsértése is táplálta. Személyisége integráltságának hiánya, széttöredezettsége megmutatkozott abban, hogy önzése, önsajnálata, bosszúvágya felülírta gyermekei iránt érzett felelősségét, szeretetét. Médeia a bosszúról való gondolkodásból fakadóan, annak megtervezésekor, kivitelezésekor és elvégzése után egyfajta paradox

\footnotetext{
${ }^{2}$ Plat. R. 585 d-e.

${ }^{3}$ Arist. EN 3. 7, ford. Szabó Miklós.

${ }^{4}$ Uo., 3. 3.
} 
örömöt érez: saját belső megelégedettségi szintje emelkedik, tudván, mekkora fájdalmat okoz gyermekei apjának.

Euripidés tragédiája igen erőszakos és rémisztő Médeia-képet mutat. A „legintenzívebb" jelenet a darabban, amikor Médeia fontolgatja, hogy megölje-e gyermekeit vagy sem. Ezt a belső vitát Euripidés feltehetően a platóni három lélekrész, azon belül

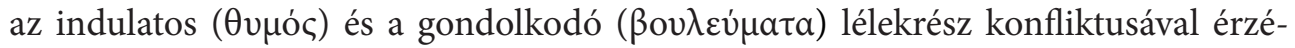
kelteti. Médeia kudarcot vall abban, hogy az ész által vezérelt lélekrészre hallgasson, bosszúvágya, haragja, indulata felülírják annak parancsait, s kikerül az ész, a racionalitás kontrollja alól. A tragédiaíró kiválóan érzékelteti azt a pszichés állapotot, amelyben az ảkpaбia, az önkontroll hiánya felülemelkedik az asszonyban. Euripidés Médeiája valószínüsíthetően a platonikus filozófia elméleti vonalát követi. Az ảkpaбía fogalmát is először Platón fejti ki Prótagoras című művében, amelyben Prótagoras a tudás erejéről beszélget:

A legtöbb ember ugyanis nem tartja valami sokra a megismerést, nem úgy gondolkodik róla, mintha valami erős, irányító, sőt parancsoló tényező volna, hanem azt állítja, hogy igen sok esetben, amikor az emberben megvan a helyes ismeret, mégsem tőle vezetteti magát, hanem valami más erőtől: hol a haragtól, hol a gyönyörtől, máskor a fájdalomtól, néha a szenvedélytől, gyakran a félelemtől. ${ }^{5}$

A hipotézis szerint az az optimális, ha a személy az ész parancsainak engedelmeskedve éli az életét, azaz tudja, hogy mi a helyes, és aszerint cselekszik; viszont ha ennek az ellenkezője történik, azaz felismeri, hogy mi lenne a helyes dolog, de - vágyai által vezérelve - azzal ellentétes módon cselekszik, akkor az ảkpaбía megmutatkozik, azaz a személy kikerül az ész kontrollja alól. Ilyen esetben az érzelmek, fóként

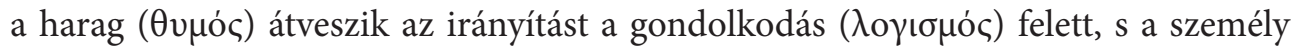
„elfelejti” annak parancsait. Euripidés Médeiájával ez történik. Az asszony tudatában

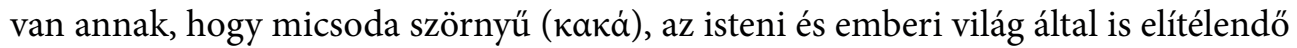
bünt szándékozik végrehajtani, s mégis megteszi, azaz hagyja, hogy destruktív vágyai, érzelmei magukkal ragadják. Az asszony „elvágja” legfontosabb kapcsolatainak fonalát, megszünik anya lenni, ily módon szélsőséges szerelmi vágyának destruktív ereje halandó voltát emeli ki, amennyiben azt a felfogást követjük, amelyet Aischylos Oresteiájában Élektra fogalmaz meg. A hajadon az Orestésszel folytatott dialógusában kifejti, hogy az utódok a halott szülő emlékének „mécsesei”, azaz megóvják őt a teljes elmúlástól, feledéstől, hiszen önmagukban, s a következő nemzedékekben emlékezetük tovább él. Ily módon Médeia szociális kapcsolatait tekintve elszigetelt ember marad, akinek emléke elenyészik az idő múlásával együtt. ${ }^{6}$

\footnotetext{
${ }^{5}$ Plat. Prt. 352 b 1, ford. Faragó László.

${ }^{6}$ D. Herbert Abel, Medea in Dido, The Classical Bulletin, 1957/58, 52.
} 
Chrysippos sztoikus filozófus - akit igencsak érdekelt az emberi psziché negatív aspektusa, a hibás döntések oka - kifejti az ảkpaбia folyamatának ezt az igen fontos elemét: szerinte egy személy nemcsak azért utasíthatja el az ész által diktált dolgokat, mert vágyai egyszerüen felülírják azokat, hanem feltételezi, hogy az érzelmek által befolyásolt állapotban ragaszkodhat is ahhoz, hogy a racionalitás kontrollja alól kikerüljön. ${ }^{7}$ Ez az állapot azért következik be, mert a đá $\theta$ oc befolyásolja a személynek azt a képességét, hogy helyesen tudjon gondolkodni és cselekedni. Chrysipposnak a pszichéről, az érzelmek hatásairól vallott nézetei föként Galénos De Placitis Hippocratis et Platonis címü müvében maradtak fenn, amelyben az orvosfilozófus vitába száll vele az emberi lélek természetének egységes vagy több részből álló elméletét illetően.

A platonikus és a sztoikus filozófia nézetei igen eltérőek abban a tekintetben,

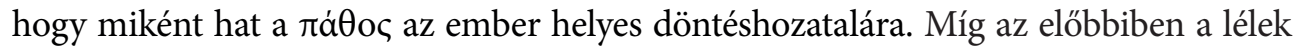
többosztatú, a sztoikus filozófiában az emberi psziché egységes. Chrysippost nagyon érdekelte Médeia akratikus állapota, miért és hogyan vált érzelmeinek rabjává. Nem az érzelmek és a racionalitás „kötélhúzásaként” értékelte a Médeia lelkében zajló folyamatokat, hanem a sztoikus lélekfilozófiát követve a psziché egységességét vallotta, így szerinte a konfliktus nem Médeia lelkének két különálló része között folyik, hanem magában Médeiában, akinek egységes pszichéje valamilyen módon két „aspektusból” vesz részt a helyzetben. Az egyetlen ember, aki képes lenne megakadályozni Médeia tettét, az Médeia önmaga, s ez ily módon nagyobb felelősséget ró rá. Az asszony mentegeti, meggondolja magát újra és újra, de haragja végül mindent felülbírál. Chrysippos szerint az ember egyfajta pszichofizikai komplexum, amelynek központi irányítója a

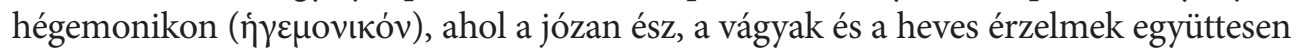
lakoznak. ${ }^{8}$ Szerinte az emóciók buja lázában nem használ a meggyőző tanítás annak, akit a szenvedély hány-vet. A harag állapotába került ember képtelen az igazság meg-

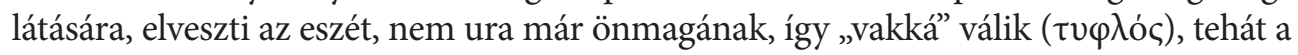
haraggal önmagának árt az ember. ${ }^{9}$

Chrysippos a futás analógiáját hozza fel annak megvilágítására, hogy milyen módon és miért cselekszik az ember a józan esze ellenére. Szerinte, ha egy személy „természetes hajtóerejével" (a motiváció alapja, cselekvésre ösztönző erő) összhangban sétál, s a lábai által kifejtett mozgás nem túlzott, akkor bármikor meg tud állni, vagy megváltoztatni tempóját. Viszont ha egy személy fut, ez már nem ilyen egyszerű. Chrysippos szerint a futáshoz hasonló dolog történik az emberi lélekben, ugyanis ha a „természetes hajtóero"” hirtelen megugrik, s több van belőle a kelleténél, akkor a léleknek meglepő és kiszámíthatatlan megnyilvánulásai lehetnek, s ebből következően az ember „furcsa” tetteket vihet véghez. Éppen emiatt ebből a hajtóerőből éppen annyira van szükség, amely mellett a józan ész és az érzelmek optimálisan tudnak

\footnotetext{
${ }^{7}$ Gal. Hipp. et Plat. 4. 5. 29-43.

${ }^{8}$ Christopher GILL, Did Chrysippus Understand Medea?, Phronesis, 1983/2, 138.

9 Änne Bäumer, Die Bestie Mensch: Senecas Agressionstheorie, ihre philosophischen Vorstufen und ihre literarischen Auswirkungen, Frankfurt am Main - Bern, Peter Lang, 1982, 67.
} 
működni. ${ }^{10} \mathrm{E}$ chrysipposi modellben a személy tudatos döntése az, amikor elkezd futni, viszont ha már fut, nem tud megállni egy pillanat alatt. Ily módon az ember képes arra, hogy tudatában legyen „árnyékának”, indulatai „elburjánzásának” - ahogyan a rohanó ember tudatában van annak, hogy lábai gyorsan mozognak -, s ezt Médeia is tudja; túlfütöttsége miatt a lélek már kényszerpályán mozog. Az asszonynak az a képessége, hogy józan eszére hallgasson, érzelmei miatt gyengül, kritikus helyzetében problémamegoldó eszközei kimerülnek, érzelmileg elszigetelödik, belső feszültsége elviselhetetlenné válik számára, személyiségének destruktív erői győzedelmeskednek, s végül elköveti végzetes tettét.

A sztoikus filozófiában az érzelmek teljes mértékben részét képezik az emberi pszichének. Nem egy alárendelt és „,idegen” lélekrész révén, hanem természetszerüleg keletkeznek bennünk, s kifejeződnek cselekedeteinkben. Chrysippos számára Médeia nem szörnyeteg, hanem olyan személy, aki - mint modelljében az ảkpaбia állapotában lévő futó ember - elvesztette kontrollját önmaga felett, azaz kapcsolatát józan eszével, s akit túlzott szenvedélyei befolyásolnak. Állapotát szerinte nem lehet teljes irracionalitásként jellemezni, annak ellenére, hogy megszűnik „emberként” müködni. Médeiával az történik, mint a futó személlyel: a józan ész negligálásával vágyainak, indulatainak mint a futó lábaknak - már nem képes tudatosan megálljt parancsolni. Chrysipposnál az ember minden esetben mint „egész” müködik, akkor is, ha ez a „működés” valamilyen szinten hibás. ${ }^{11} \mathrm{E}$ modell szerint Médeia, akit indulatai magával ragadnak, nem tudja és nem is akarja megállítani a lelkében zajló folyamatot, $s$ annak intenzitását enyhíteni. Iasón iránti szerelme és bosszúvágya kontrollálja létezését, megsemmisíti alapvető értékeit, azaz a női lét egyik legfontosabb szerepében vall kudarcot gyermekei meggyilkolásával.

Galénos is Médeiát hozza fel példaként filozófiájának alátámasztására. Az asszony lelkét nem egységesnek, hanem platóni hatásra három lélekrészből állónak tekinti, s a konfliktust ezek között értelmezi, amelyből az érzelmekért „felelős” lélekrész kerül ki győztesen. Galénos szerint Médeia tudta, hogy istentelen és szörnyü dolgokat fog csinálni, mikor elhatározta, hogy megöli gyermekeit, habozott, majd a harag újból elragadta, mint mikor az engedetlen ló átveszi az irányítást a kocsihajtótól; majd a józan ész ismét felülkerekedett, aztán a düh, majd megint az ész. Tehát folyamatosan e kettő között hánykódott, amikor átengedte magát a haragnak. ${ }^{12}$ Galénosnál e három lélekrész (a józan gondolkodásért, a vágyakért és a haragért felelős lélekrészek) a psziché három különböző része, amelyek a test különböző területein helyezkednek el. ${ }^{13}$ Kifejti, hogy Euripidés Médeiát a „barbár” és műveletlen ember exemplumaként hozza fel, akinek lelkében a harag és az indulat erősebb a józan észnél; ugyanakkor a görögök

\footnotetext{
${ }^{10}$ Gal. Hipp. et Plat. 4. 2. 14-18.

${ }^{11}$ GILL, i. m., 140.

${ }^{12}$ Gal. Hipp. et Plat. 3. 3. 14.

${ }^{13}$ Christopher Gill, Personality in Greek Epic, Tragedy and Philosophy: The Self in Dialogue, Oxford, Oxford University Press, 1996, 231-234.
} 
és a művelt emberek esetében - mint Odysseus - a psziché értelmes része minden esetben felülkerekedik az érzelmeken. Szerinte ezen állapot eléréséhez a filozófia gyakorlása elengedhetetlen, s akik ezt nem teszik - például a „barbárok”, gyermekek -, azokat a harag befolyásolja döntéseikben. Galénos értetlenül áll Chrysippos Médeiát elemző, exemplumjellegű lélekfilozófiája előtt, hiszen szerinte éppen saját, sztoikus elméletét cáfolja meg vele. ${ }^{14} \mathrm{Az}$ orvosfilozófus a későbbi sztoikus, Poseidónios lélekfilozófiáját hozza fel nézetének megerösítésére, aki a „platóni” modell irányvonalához tér vissza. Sztoikus létére úgy gondolta, hogy a morális fejlődéshez elengedhetetlen a lélekben lévő irracionális rész manifesztációjának megfékezése, és erre a lelket már gyermekkorban fel kell készíteni, „megerösíteni”. ${ }^{15}$ Poseidónios szerint a „chrysipposi intellektualizmus" helytelen felfogást képvisel, mivel megfeledkezik a platóni tanításról, a lélekben müködő irracionális erőkről. Szerinte a sztoikus filozófia nem fejtheti meg az érzelmek helyes működését anélkül, hogy e tételeket figyelembe ne venné. Ugyanakkor Poseidónios nem hirdet teljes érzelemmentességet, kizárólag a destruktív, mértéktelen, „Médeia-féle” érzelmi megnyilvánulásokat tekinti veszélyesnek és elkerülendőnek, amelyek felülkerekedhetnek a racionális gondolkodáson. ${ }^{16}$

A lélek ingadozásának sztoikus modelljét Plutarchos is kifejti Moralia címü müvében. Leírja, hogy némelyek szerint az érzelem lényegében nem különbözik a

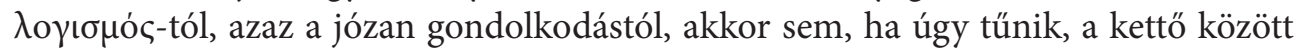
viszály támad, hiszen az csak egyetlen ok felbomlása két aspektusra. Ezek az érzelmek hozzájárulnak és ösztönzik a döntéshozatalt, aktivitási erők, amelyek egy pillanat alatt bármely irányban megváltoztathatják az ember elhatározását. Példának hozza a gyermekek hirtelen támadt erőszakos és heves tetteit, amelyek bizonytalanok és ingatagok a "gyermeki gyengeség” következtében. ${ }^{17}$

Apollónios Rhodios Médeiájának lélekábrázolása is - a korabeli sztoikus filozófiai gondolkodást követve - a lélek egységét hangsúlyozza. A chrysipposi nézethez hasonlóan egy, az euripidési Médeia-alaknál tudatosabb, személyisége „árnyékát” inkább ismerő asszony tárul elénk. ${ }^{18}$ Éppen emiatt az olvasóban önkéntelenül némi együttérzés alakulhat ki, mivel betekintést nyer az asszony döntési folyamatába, érzelmi zürzavarába. Euripidés Médeia-karakterét az irracionalitás, a „bestiális” (nem árnyaltan elemzett) impulzusok irányítják. Apollónios Rhodios Médeiája árnyaltabb képet ad. Chrysippost és a sztoikus filozófiát vallókat követve olyan Médeiát állít

\footnotetext{
${ }^{14}$ Gal. Hipp. et Plat. 3. 3. 13.

${ }^{15}$ Robert W. Sharples, Stoics, Epicureans and Sceptics: An Introduction to Hellenistic Philosophy, New York, Routledge, 1996, 71.

${ }^{16}$ Richard SoRABJI, Posidonius On the Irrational Forces In Emotion = R. S., Emotion and Peace of Mind: From Stoic Agitation to Christian Temptation, Oxford, Oxford University Press, 2002, 94-95.

${ }^{17}$ Plutarchos, Moralia, 446.

${ }^{18}$ A sztoikusok szerint minden olyan deviancia, amely eltér az „univerzális” racionalitás elveitől, azt eredményezi, hogy a személy elveszíti kapcsolatát józan eszével, s eltekint a racionalitás további alkalmazásától. A sztoikus filozófiában az individuum felelős önmagáért és érzelmeiért.
} 
elénk, aki - mint minden ember - elválaszthatatlan érzelmeitől s azok kifejezésétől. ${ }^{19}$ Használja az introspekció módszerét, elemzi érzelmeit, s tudatában van azok destruktív erejének. Apollónios az asszonyt inkább az erós áldozataként mutatja be, mintsem a gonoszság legfőbb megtestesítőjeként. Médeia karakterét az olvasó már leánykorától kezdve ismeri, tanúja szerelme kibontakozásának, hazaárulásának, egyúttal lelki küzdelmének a szerelem végzetes vágya és a hazája miatti szégyenérzet között. Ily módon - teljes mértékben betekintést nyerve Médeia lelki történéseibe, $s$ az ok-okozati összefüggések folyamatába - a szerző az asszony tettének okát az erós által létrejött destruktív és módosult tudatállapotban láttatja, amely állapot szerinte legalább annyira sajnálatra méltó, mint büntetendő. ${ }^{20}$

Chrysippost követve Epiktétos sztoikus filozófus is kifejti a Médeia lelkében zajló folyamatokat, segítségül hívva Euripidés híres sorait (1078-1080). A filozófus Beszélgetések címü művében ki is fejti, hogy Médeia iránt inkább sajnálatot, mint haragot kellene éreznünk, mert a szegény asszony eltévedt, azaz indulatai téves irányba vezették a legfontosabb kérdésekben, s emberből viperává alakult át. Inkább szánjuk őt, ahogy szánjuk a vak vagy a béna embert, mert ő is vakká és bénává lett döntési képességeiben. ${ }^{21}$ Leírja, hogy Médeia fokozatosan feladja minden reményét, hogy megtartsa Iasónt, hogy Korinthosban maradjon, hogy nincs senkije, aki megvédené őt, $\mathrm{s}$ kétségbeesésében a legnagyobb hibát követi el. ${ }^{22}$ Epiktétos szerint Médeia haragja fokozatosan elhomályosítja az asszony józan ítélőképességét, ugyanakkor nem cselekedhet anélkül, hogy „egész lényében” ne lenne jelen, ily módon az egységes lélek döntéseként értelmezi tettét. ${ }^{23}$

Kilikiai Simplikios újplatonikus filozófus létére a sztoikus Epiktétos Kézikönyvecskéjéhez írt kommentárokat. Háromszor is használja a híres sorokat, melyeket Chrysippos és Epiktétos is elemez. ${ }^{24} \mathrm{Az} 5$. fejezetben így ír:

Vétkes tett ugyanis vagy akkor következik be, amikor az értelem a gyakorlati okosság fogyatékos volta miatt nem határozza meg, hogy mit kell tennie, vagy akkor, amikor az értelem [...] látja ugyan, hogy mit kellene megtennie, ám képzetlensége miatt az irracionális törekvések zsarnoki módon föllázadnak az értelem ernyedt ítélete ellen, mint mikor a tragédiában a Médeiát

\footnotetext{
${ }^{19}$ Julia Simons, "And Her Heart Fluttered": The Psychopathology of Desire in the Argonautika, Kelburn, Victoria University of Wellington, 2014, MA-záródolgozat kézirata, 39. https://core.ac.uk/download/ pdf/41338978.pdf (Letöltés ideje: 2017. április 30.)

${ }^{20}$ Uo., 4.

${ }^{21}$ Epikt. Ench. 1. 28. 7.

${ }^{22}$ John M. Dillon, Medea among the Philosophers = Medea: Essays on Medea in Myth, Literature, Philosophy and Art, eds. James J. Clauss, Sarah I. Johnston, Princeton, Princeton University Press, 1997, 217.

${ }^{23}$ Uo., 214.

${ }^{24}$ Marilynn Lawrence, Akrasia and Enkrateia in Simplicius's Commentary on Epictetus's Encheiridion = The Neoplatonic Socrates, eds. Danielle A. Layne, Harold Tarrant, Philadelphia, University of Pennsylvania Press, 2014, 135.
} 
alakító színész azt mondja: „Tudom, hogy szörnyü bűn, amit merészelek, / de elmémnél hatalmasabb a szenvedély."25

Galénos Médeia-interpretációjához hasonlóan több platonikus szövegben is feltünik az euripidési passzus a platóni háromosztatú lélekteória bizonytékaként, egyfajta exemplumtörténetként arról, hogy a lélek irracionális része képes felülkerekedni a racionális részen. Alkinoos De doctrina Platonis címü művének 24. fejezetében a lélek részeinek tárgyalásakor Médeiát hozza fel példaként a $\theta v \mu o ́ c$ létét és erejét illetően, amely a lélekben a józan ész ellentéteként működik. Calcidius Platón Timaios című művéhez írt kommentárjának 183. fejezetében a sorsról értekezve említi meg exemplumként a gyermekgyilkos asszonyt, azaz hogy miképp tud a $\theta v \mu o ́ \varsigma$ felülemelkedni az emberi lélek értelmes részén. ${ }^{26}$

Az antikvitás során a Médeia lelkében végbemenő folyamatokat, $s$ a híres sorokat nemcsak a filozófusok, hanem az írók, költők is magyarázzák, lélekfilozófiai elméleteiket támasztják alá vele, vagy akár frivol módon használják fel azt, mint Lukianos. A híres szatíraíró élete végén elfogad egy császári hivatalt Egyiptomban, ugyanakkor éles szatírát ír az ilyesfajta munkák „etikájáról”. Médeia szavait parodizálva mentegeti magát: szegénysége hatalmasabb elméjénél. ${ }^{27}$ Megfigyelhető továbbá a passzus használata többek között Ailios Aristeidésnél (Oratio 34. 50), Alexandriai Szent Kelemennél (Stromata 2. 15. 63.3), Synesiosnál (De regno 10), Hieroklésnél (Pythagoras aranyverseihez írt kommentárjaiban, 6-7), Stobaiosnál (Florilegium 3. 20. 37) és Éliasnál (Prolegomena philosophiae 10) is. ${ }^{28}$

Az ókori görög tudósok, filozófusok elöszeretettel hozták fel példaként téziseik alátámasztására a görög mitológia karaktereinek tetteit, s elemezték ezek mozgatórugóit, a lélekben végbemenő pszichés folyamatokat. A Médeia-mítosz lélektanát, az asszony lelkében dúló destruktív indulati folyamatok mibenlétét $s$ háttértényezőit több gondolkodó értelmezte már az antikvitás folyamán. Az általános görög filozófiai gondolkodásban az asszony a kegyetlen, veszélyes, barbár, néhol a sajnálatra méltó ember prototípusa marad, aki a dezorientált psziché paradigmatikus exemplumát testesíti meg. ${ }^{29}$ A történet lélektani aspektusának kulcsfontosságát jelzi, hogy - bár majd 2500 év telt el az emberiség történetében a dráma első, euripidési megjelenése óta - nem vesztett jelentőségéből azóta sem, sőt a téma által megjelenített lelki jelenség a mai napig kutatás tárgyát képezi a pszichológia és pszichiátria tudományterületén. A mítosz szolgáltatta az alapot a Médeia-komplexus pszichológiai terminusának modernkori megszületéséhez is, amely fogalom a „Médeia-anyát” mint egy narcisztikus,

\footnotetext{
${ }^{25}$ Szimplikiosz kommentárja Epiktétosz Kézikönyvecskéjéhez, ford. STEIGER Kornél, Bp., Gondolat, 2016, $28-29$.

${ }^{26}$ Dillon, i. m., 215.

${ }^{27} \mathrm{Uo}$.

${ }^{28}$ Uo., 216.

${ }^{29}$ Uo., 218.
} 
megsebzett, reményvesztett, függésben lévő nőt írja le, aki kíméletlen kegyetlenséggel „elvágja” a szülö-gyermek kapcsolatot, és bosszút áll férjén gyermekei révén.

\section{KaTALIN BÁN}

Medea, the infanticide in the light of the ancient Greek psychological perception

The ancient Greek scholars and philosophers relished to use the deeds of Greek mythological figures as examples to demonstrate their theses, to analyse their motives and psychic processes in the soul. The Medea-myth, its psychology, the destructive emotion processes and their background factors in the woman's soul have been interpreted by several scholars during antiquity in particular through the key lines of Euripides' drama (1078-1080) to demonstrate their own philosophical theses. In the general Greek philosophical thinking, Medea remains the prototype of a cruel, dangerous, barbarian, occasionally regretful woman who embodies the paradigmatic exemplar of the disoriented psyche. 